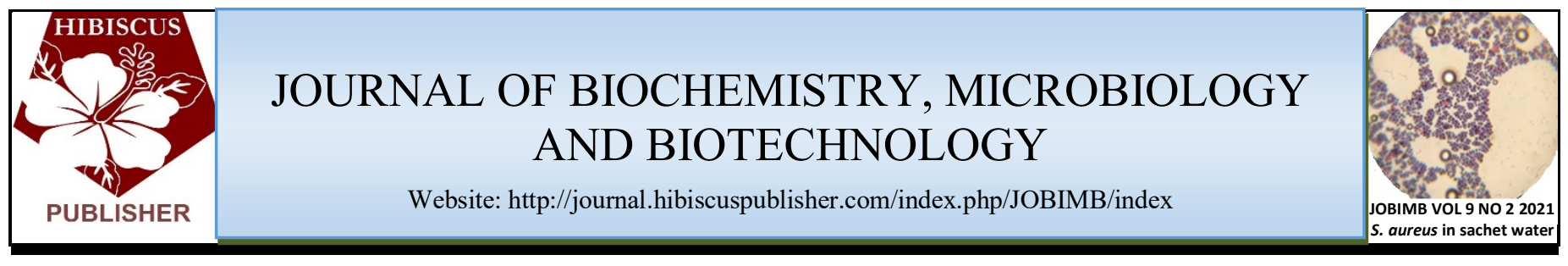

\title{
Effects Of High Dosage of Codeine - Containing Cough Syrup Administration on Some Biochemical Parameters of Liver in Albino Rats
}

\author{
Aishatu Bello ${ }^{1}$, Ramlatu Musa Adam ${ }^{1}$, Fatima Umar Maigari ${ }^{1}$, Idi Jalil James ${ }^{1}$, Abubakar Aisami ${ }^{1 *}$ \\ ${ }^{1}$ Biochemistry Department, Gombe State University, P.M.B 127, Tudun Wada, Gombe, Nigeria. \\ *Corresponding author: \\ Dr. Abubakar Aisami, \\ Biochemistry Department, \\ Gombe State University, \\ P.M.B 127, \\ Tudun Wada, \\ Gombe, \\ Nigeria. \\ Email: abubakar.aisami05@gmail.com
}

\begin{tabular}{l}
\hline HISTORY \\
Received: $15^{\text {th }}$ Sep 2021 \\
Received in revised form: $24^{\text {th }}$ Nov 2021 \\
Accepted: $15^{\text {th }}$ Dec 2021 \\
\hline KEYWORDS \\
Codeine \\
Hepatotoxicity \\
Bilirubin \\
Aspartate aminotransferase \\
Alkaline phosphatase
\end{tabular}

\begin{abstract}
The study aimed to determine the effect of a high dosage of codeine-containing cough syrup administration on some biochemical parameters of the liver in albino rats. Codeine at 80 $\mathrm{mg} / \mathrm{kg} /$ day, $160 \mathrm{mg} / \mathrm{kg} /$ day, $240 \mathrm{mg} / \mathrm{kg} /$ day, $320 \mathrm{mg} / \mathrm{kg} /$ day cough syrup were administered orally to albino rats for 21 days, biochemical parameters were analyzed for the activities of Alanine aminotransferase (ALT), Aspartate aminotransferase (AST), Alkaline phosphatase (ALP), Bilirubin, Total protein and Albumin. Results obtained revealed that a high dosage of codeine administration significantly increased plasma levels of alanine aminotransferase (ALT), aspartate aminotransferase (AST), alkaline phosphatase (ALP), bilirubin and albumin while it reduced total protein level when compared with the control rats. The study confirmed the risk of increased hepatotoxicity due to a high dosage of codeine administration. Although codeine is reported to be effective in pain management, its toxicity should be kept in mind.
\end{abstract}

\section{INTRODUCTION}

Codeine is an opioid that functions as an ingredient in multiple medications. It helps alleviate mild to moderate pain and suppress coughing. The drug is often used to suppress a cough either alone or by combining it with other drugs [1]. The major pharmacological effects of codeine such as analgesia, drowsiness, mood changes, respiratory depression, nausea, and decreased gastrointestinal motility are produced on the central nervous system (CNS) and gastrointestinal tract [2]. The metabolism of codeine occurs mostly in the liver, and to a lesser extent in the intestine and central nervous system [3].

Although codeine metabolism resulted in several metabolites, it is morphine, a product of codeine O-demethylation by enzyme cytochrome P 450 2D6 (CYP 2D6), that is responsible for its analgesic effect $[4,5]$. Codeine dosage is highly regulated; its overdose could cause depressive effects on the central nervous system or death from respiration arrest. The adult minimum lethal oral dose for codeine is estimated to be $0.5-1.0 \mathrm{~g}$, i.e $17-$ 34 pills containing $30 \mathrm{mg}$ codeine [6]. The serum codeine concentrations exceeding $0.3 \mathrm{mg} / \mathrm{l}$ have been reported to cause toxicity, while concentrations above $1.6 \mathrm{mg} / \mathrm{l}$ are considered to be lethal [2].

Codeine is structurally similar to morphine. In fact, when someone uses codeine, their liver metabolizes the drug as morphine. People respond differently to codeine partially because each person's liver metabolizes morphine differently. The involvement of the liver in breaking down Codeine once it enters the body's systems is the reason why Codeine abuse sometimes inflicts liver damage. When someone's liver metabolizes codeine quickly, they are at greater risk of an overdose. In recent years, codeine has contributed to the high rates of addiction and overdose which have characterized the Opioid epidemic [7].

The abuse and misuse of prescription opioids such as codeine have reached an alarming rate in the last ten years. In the United States, it was reported that about 1.2 million visit the emergency department (ED) as a result of non-medical use of prescription medications in 2011 alone [7]. The production and importation of cough syrup that include codeine as an ingredient was banned by the Nigerian Government in 2018 due to concerns regarding its use by youths to get intoxicated [8]. 
Many addicts of codeine in many countries are into the habit of using the drug every day without doctor prescriptions which is of great concern. Therefore, this study determined the effect of a high dosage of codeine-containing cough syrup on biochemical parameters of the liver in albino rats given orally for 21 days.

\section{MATERIALS AND METHODS}

\section{Reagents and chemicals}

Codeine was obtained from Sigma-Aldrich Chemical Co. Ltd.(England), The analytical grade reagent obtained from Randox Laboratories Ltd, Antrim United Kingdom and Biosystems Reagents and Laboratories, Costa Bravo Barcelona, Spain were used for the analysis. The kits used include ALT, AST, ALP and bilirubin kits. Sodium potassium tartrate, Potassium iodide, Succinic acid, and Bromocresol green.

\section{Animals}

Twenty-five (25) albino rats of both sexes body weight ranges from (84 to $232 \mathrm{~g}$ ) were obtained from National Veterinary Research Institute Vom, Jos, the animals were kept in cages in the animal house of Biological sciences Department, Gombe State University, they were allowed fourteen (14) days to acclimatize before the commencement of drug administration. The animals were maintained with a normal diet such as (grower's marsh, vital feeds and distilled water) throughout the acclimatization and administration period. The animal experimental procedures were conducted in accordance with the National Institutes of Health guide for the care and use of laboratory animals (NIH Publications No. 8023) revised in 2002 and approved by the institutional research committee.

\section{Experimental design}

The animals were divided into five (5) groups according to their weight with four (4) rats in each group, a group I, II, III, and IV, were the study groups and group V served as a control group. Rats in-group I and II were administered orally with $80 \mathrm{mg} / \mathrm{kg}$ and $160 \mathrm{mg} / \mathrm{kg}$ of codeine cough syrup (Tutolin with codeinecontaining cough syrup) respectively. The animals in groups IV and $\mathrm{V}$ were administered orally with $240 \mathrm{mg} / \mathrm{kg}$ and $320 \mathrm{mg} / \mathrm{kg}$ of codeine-containing cough syrup ((Tutolin with codeinecontaining cough syrup) respectively. The animal's in-group V (Control) was administered with distilled water. The administration of the cough syrup was done once every (24) hour for the period of three weeks as shown in table 1 .

Table 1. Experimental design.

\begin{tabular}{lcccc}
\hline Group & $\begin{array}{c}\text { Number of } \\
\text { Animals }\end{array}$ & $\begin{array}{c}\text { Average Weight } \\
\text { of Rats }(\mathrm{g})\end{array}$ & $\begin{array}{c}\text { Dose } \\
(\mathrm{mg} / \mathrm{kg})\end{array}$ & $\begin{array}{c}\text { The volume of } \\
\text { Cough Syrup }(\mathrm{ml})\end{array}$ \\
\hline 1 & 4 & 150.40 & 80 & 0.6 \\
2 & 4 & 164.00 & 160 & 1.6 \\
3 & 4 & 190.40 & 240 & 2.9 \\
4 & 4 & 233.80 & 320 & 4.6
\end{tabular}

\section{Collection and preparation of blood samples}

At the end of the third week of oral administration of codeinecontaining cough syrup, the rats were sacrificed by decapitation. Blood samples were collected into centrifuge tubes. The blood was allowed to clot at room temperature for 5 minutes, after which an applicator stick was used to carefully loosen the blood. The blood was then centrifuged at 3000rpm for 5 minutes. A clean Pasteur pipette was used carefully to collect the serum and dispensed into a clean-labelled specimen bottle. Sera samples collected were analyzed for activities of alanine aminotransferase (ALT), aspartate aminotransferase (AST), alkaline phosphatase (ALP), bilirubin, total protein and albumin.

\section{Determination of blood biochemical parameters}

Plasma concentrations of alanine aminotransferase (ALT), aspartate aminotransferase (AST), alkaline phosphatase (ALP), bilirubin were determined using enzymatic kits total protein by using biuret method and albumin using Bromo - cresol green method

\section{Statistical analysis}

Results are expressed as mean \pm S.E.M. The levels of homogeneity among the groups were assessed using a one-way Analysis of Variance (ANOVA) followed by a pos hoc test. All analyses were done using Statistical package for social sciences (SPSS) software (version 25.0) and $\mathrm{p}$ values $<0.05$ were considered statistically significant.

\section{RESULTS}

Effect of high dosage of codeine-containing cough syrup administration on AST, ALT and ALP activities

Administration of codeine-containing cough syrup at $80 \mathrm{mg} / \mathrm{kg}$, $160 \mathrm{mg} / \mathrm{kg}, 240 \mathrm{mg} / \mathrm{kg}$ and $320 \mathrm{mg} / \mathrm{kg}$ doses significantly increased the activity of AST by $18.1 \%, 19.0 \%, 22.1 \%, 23.5 \%$ respectively, ALT activity by $17.0 \%, 18.7 \%, 21.9 \%, 26.0 \%$ respectively and ALP activity by $16.7 \%, 17.5 \%, 21.9 \%, 27.9 \%$ respectively when compared with the normal rats (Table 1).

Table 1. Effect of high dosage of codeine-containing cough syrup administration on AST, ALT and ALP activities.

\begin{tabular}{lccccc}
\hline Parameters & Control & Group 1 & Group 2 & Group 3 & Group 4 \\
\hline ALT (I/U) & $52.39 \pm 0.36$ & $54.19 \pm 0.48$ & $59.40 \pm 0.31^{* *}$ & $69.57 \pm 2.15^{* *}$ & $82.73 \pm 2.01^{* *}$ \\
AST (I/U) & $52.07 \pm 0.72$ & $54.92 \pm 0.53$ & $57.57 \pm 0.41^{* *}$ & $67.10 \pm 0.54^{* *}$ & $71.31 \pm 1.29^{* *}$ \\
ALP (I/U) & $149.39 \pm 0.85$ & $155.01 \pm 0.67$ & $162.10 \pm 1.22^{* *}$ & $202.91 \pm 2.61^{* *}$ \\
$259.17 \pm 1.62^{* *}$ & \\
Note: Each value represents the mean of 4 rats. ${ }^{* * *}=$ significantly different from the control $(\mathrm{p}<$ \\
0.05).
\end{tabular}

Effect of high dosage of codeine-containing Cough Syrup Administration on Billirubin

Administration of codeine codeine-containing cough syrup at 80 $\mathrm{mg} / \mathrm{kg}, 160 \mathrm{mg} / \mathrm{kg}, 240 \mathrm{mg} / \mathrm{kg}$ and $320 \mathrm{mg} / \mathrm{kg}$ doses significantly increased billirubin level by $9.3 \%, 19.5 \%, 22.7 \%$ and $37.9 \%$ respectively when compared with the control group (Table 2).

Table 2. Effect of high dosage of codeine-containing cough syrup administration on billirubin.

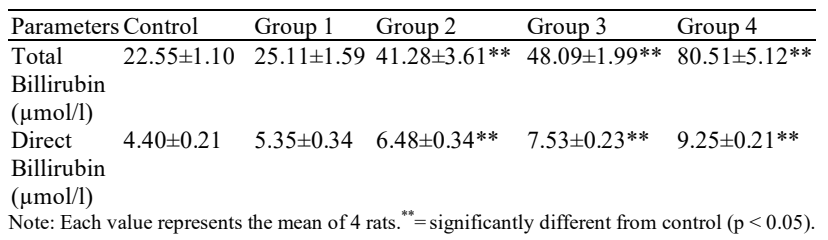

Effect of high dosage of codeine-containing cough syrup administration on total protein and albumin

Administration of codeine-containing cough syrup at $80 \mathrm{mg} / \mathrm{kg}$, $160 \mathrm{mg} / \mathrm{kg}, 240 \mathrm{mg} / \mathrm{kg}$ and $320 \mathrm{mg} / \mathrm{kg}$ doses significantly decreased total protein level by $22.9 \%, 20.5 \%, 17.5 \%$ and $14.3 \%$ respectively when compared with the control group. Albumin level was significantly increased by $18.2 \%, 19.7 \%, 21.2 \%$ and $23.9 \%$ respectively when compared with the control group (Table 3). 
Table 3. Effect of high dosage of codeine-containing cough syrup administration on total protein and albumin.

\begin{tabular}{llllll}
\hline Parameters & Control & Group 1 & Group 2 & Group 3 & Group 4 \\
\hline Albumin $(\mathrm{g} / \mathrm{l})$ & $3.88 \pm 0.15$ & $3.85 \pm 0.10$ & $4.05 \pm 0.06$ & $4.35 \pm 0.06^{*}$ & $5.13 \pm 0.15^{* *}$ \\
Total protein $7.23 \pm 0.27$ & $6.68 \pm 0.28$ & $5.98 \pm 0.17^{* *}$ & $5.1 \pm 0.29^{* *}$ & $4.18 \pm 0.13^{* *}$ \\
$(\mathrm{~g} / \mathrm{l})$ & \\
Note: Each value represents the mean of 4 rats. ${ }^{* *}=$ significantly different from control $(\mathrm{p}<0.05)$
\end{tabular}

\section{DISCUSSION}

Codeine (Opioid) is an analgesic mainly used as an antitussive drug and to manage mild to moderate pain $[9,10]$. It is however, a drug of abuse because of its stimulatory effect on the central nervous system among some adults [11]. Toxic effects of codeine use have been reported, although little is known about codeine toxicity mechanisms $[12,13]$. In this study, the toxic effects of codeine were examined in animal models. Codeine was studied as a drug and not as an analgesic because the alarming misuse of codeine recently made Nigeria Government ban the production and importation of cough syrup that has codeine as an ingredient [8]. Therefore, this study determined the toxicity of a high dosage of codeine on the liver because people use codeine without doctor prescriptions.

In this study, many biochemical parameters on liver function were determined in plasma samples to assess damage to the metabolizing organ. The increase in the activities of alanine aminotransferase (ALT), aspartate aminotransferase (AST), and alkaline phosphatase (ALP) has been reported in previous studies following exposure to opioids, including morphine and tramadol $[14,15,16]$. Administration of codeine in this study significantly increased ALT, AST and ALP activities which conform with previous research that revealed that AST, ALP and ALT activities in plasma increased significantly in an addicted patient of opioids [17]. The liver is an organ that detoxified toxic elements and chemical drugs in the body, the increase in the activities of ALT, AST and ALP in plasma in this study are indicative of liver damage [18]. The increased secretion of these liver enzymes may be accompanied by acute cell necrosis, therefore, the increased plasma level of these enzymes in rats treated with codeine could be due to necrosis or damage to the liver cell membrane which leak the enzymes into the blood circulation.

Administration of codeine in this study significantly increased bilirubin which is similar to previous studies following exposure to acetaminophen, morphine, antimalaria drugs, and oral contraceptives [19]. There was a decrease in plasma total protein in rats treated with codeine in this study this is in support of previous research findings which showed a decrease in plasma total protein levels in opium dependent participants when compared to the control group [20]. The clinical diagnosis has shown that a decrease in plasma concentrations of protein characterized by significant increases in the urinary excretion of protein and albumin are indicators of renal dysfunction [21]. Therefore, the decrease in plasma total protein observed in this study can be taken as an indication of kidney damage.

\section{CONCLUSION}

The results indicate that a high dosage of codeine-containing cough syrup administration may cause hepatotoxicity and as such, its use should be limited to prescription only. The findings underlined the need to avoid indiscriminately and prolong the use of codeine, since prolonged daily use of the drug either at a therapeutic dose or the extreme dose may lead to damage accumulation.

\section{REFERENCE}

1. Frost J, Helland A, Nordrum IS, Slordal L. 2012. Investigation of morphine and morphine glucuronide levels a cytochrome P 450 isoenzyme 2D6 genotype in codeine related deaths, Forensic Sci. Int. 220:6-11.

2. Jaffej H, Martin WR. 1980. Opioid analgesics and antagonists. The Pharmacological Basis of Therapeutics (Gilman AG, Goodman LS, Gilman A, Eds.). 6th Ed., Macmillian Co., New York. 494-534.

3. Frost J, Løkken TN, Helland A, Nordrum IS, Slordal L. 2016. Postmortem levels and tissue distribution of codeine, codeine-6glucuronide, norcodeine, morphine and morphine glucuronides in a series of codeine-related deaths. Forensic Sci. Int. 262:128-137.

4. Poulsen L, Brosen K, Arendt-Nielsen L, Gram LF, Elbaek K, Sindrup SH. 1996. Codeine and morphine in extensive and poor metabolizers of sparteine: Pharmacokinetics, analgesic effect and side effects. Eur. J. Clin. Pharmacol. 51:289-295.

5. Sindrup SH, Arendt-Nielsen L, Brosen K, Bjerring P, Angelo HR, Eriksen B, Gram LF. 1992. The effect of quinidine on the analgesic effect of codeine. Eur. J. Clin. Pharmacol. 42:587-591.

6. Baselt RC. 2008. Disposition of Toxic Drugs and Chemicals in Man, 8th Ed., Biomedical Publications, Foster City.

7. Drug Abuse Warning Network (DAWN) 2013. National estimates of drug-related emergency department visits.

8. O'Grady S. 2018. Nigeria bans codeine cough syrup to stop an addiction epidemic. But something worse could take its place. The Washington Post. available:https://www.washingtonpost.com/news/worldviews/wp/.

9. Gasche Y, Daali Y, Fathi M, Chiappe A, Cottini S, Dayer P, Desmeules J. 2004. Codeine intoxication associated with ultra rapid CYP 2D6 metabolism. N. Engl. J. Med. 351:2827-2831.

10. Barnhart ER. 1986. Physicians' Desk Reference, Medical Economics Company, Oradell, NJ. 40th Ed.

11. Fraser HF. 1972 . Patterns of abuse of narcotics: An historical overview. In drug abuse- Proceedings of the International Conference Lea \& Febiger, Philadelphia (Zarafonetis CJD, Ed.), 141-I51.

12. Frost J, Helland A, Nordrum IS, Slordal L. 2012. Investigation of morphine and morphine glucuronide levels a cytochrome P 450 isoenzyme 2D6 genotype in codeinerelated deaths, Forensic Sci. Int. 220:6-11.

13. Schulz M, Schmoldt A. 2003. Therapeutic and toxic blood concentrations of more than 800 drugs and other xenobiotics. Pharmazie. 58(7):447-474.

14. Ali OK, Ahmed AJS, Mawlood AG. 2015. Effects of tramadol on histopathological and biochemical parameters in male rabbits. Am. J. Biol. Life Sci. 3:85-90.

15. Hafez E, Issa S, Rahman SA. 2015. Parenchymatous toxicity of tramadol: A histopathological and biochemical study. J. Alcohol Drug Depend. 3.

16. Salahshoor MR, Khashiadeh M, Roshankhah S, Kakabaraei S, Jalili C. 2016. Protective effect of crocin on liver toxicity induced by morphine. Res. Pharm. Sci. 11:120-129.

17. Sajad M, Chawla R, Zargan J, Umar S, Sadaqat M, Khan HA. 2011. Cytokinetics of adult rat SVZ after EAE. Brain Research.1371:140149 .

18. Salashoor MR, Roshankhan S, Hosseni P, Jalili C. 2018. Genistein improves liver damagein male mice exposed to morphine. Chinese Medical Journal (Engl). 131(13):1598-1604. 
19. Jorgen L. Herrera. 2012. Advancing Gastroenterology, improving patient care. American college of Gastroenterology. 6400.

20. Afarinesh MR, Haghpanah T, Divsalar K, Dehyadegary E, ShaaikhAleslami A, Mahmoodi M. 2014. Changes in serum biochemical factors associated with opium addiction after addiction desertion. Addiction and Health. 6:138-145.

21. Garg R, Yusuf S. 1995. Overview of randomized trials of angiotensin-converting enzyme inhibitors on mortality and morbidity in patients with heart failure. Collaborative Group on ACE Inhibitor trials. JAMA. 273(18):1450-1456 